\title{
Role of Silicon in Mitigating Effects of Deficit Irrigation on Production of Sorghum (Sorghum Bicolor L.) Under Arid Land Conditions
}

\author{
Burhan A. M. Niyazi and Aaftab Ahmad \\ Department of Hydrology and water resources management, \\ King Abdulaziz University Jeddah, \\ Saudi Arabia
}

\begin{abstract}
Growth of sorghum under irrigation water stress i.e. under reduction of irrigation water from $100 \%$ to $60 \%$ ETc resulted in significant reduction in growth components of sorghum. Plant height, number of tillers and total fresh forage yield decreased with decrease in irrigation water from $100 \%$ to $80 \%$ and $60 \%$ ETc. Folliar application of silicon mitigated and alleviated the harsh conditions created by drought stress on sorghum plant growth. Silicon when applied at concentration of $2 \mathrm{~kg} / \mathrm{ha}$ with water stress level $2(80 \% \mathrm{ETc})$ gave the maximum plant height $(109.0 \mathrm{~cm})$ and the maximum fresh forage yield (44.00 t/ha) compared to control treatment $(100 \%$ ETc). Root volume was maximum $(0.031 \mathrm{m3})$ under $60 \%$ ETc and $2 \mathrm{~kg}$ ha-1 $\mathrm{Si}$ treatments compared with control $(100 \%$ ETc). For production of sorghum fodder under the arid land environmental conditions of Saudi Arabia deficit irrigation with $(80 \%$ and $60 \% \mathrm{ETc})$ with application of $2 \mathrm{~kg}$ ha-1 silicon (Si) as foliar spray seems a reasonable option than irrigating the crop with $100 \%$ ETc due to scarcity of irrigation water in this country. It gives higher yields than $100 \%$ irrigation and optimum moister level in the root zoon.
\end{abstract}

Key words: Sorghum bicoloeL., drought stress, silicon foliar spray

\section{INTRODUCTION}

Saudi Arabia demands for green forage is ever increasing due to the rapidly expanding livestock industry particular in dairy animals. Sorghum bicolor L forage crop may be one of the solutions to this problem for it is a drought resistant crop and can grow in limited irrigation water, to give very low cost fodder. (Marsalis et al., 2009). It is an animal fodder cereal crop and also human food belonging to Poaceae family and is cultivated in all around the world particularly in arid regions. Plants mostly suffer from drought stress more than from any other factor, and drought stress on crop production is more harmful as compared to other environmental stresses (Dreesen et al., 2012; Rollins et al., 2013). The decrease in rainfall events, continuous water losses, high ambient air temperature and bad irrigation practices during growing season causes drought stress in a specific region (Lobell et al., 2011; Vadez et al., 2011; 2012; Wahid et al., 2007; Trenberth, 2011). Leaf area index (LAI) and shoot to root ratio are greatly reduced due to drought stress which ultimately results in reduction of whole plant growth and development (Anjum, et al., 2011b). Due to drought stress, the diffusion of carbon dioxide from the atmosphere decreases in plants which causes in low photosynthetic activity (Keenan, et al., 2010). In plants, Si concentration varies from 0.1 to $10 \%$ of dry weight according to genotypes
(Hodson et al., 2005). Si regulates the nutrients uptake in many crops particular under environmental stresses (Wallace, 1993; Ma and Takahasi, 2002). When applied, in proper amount, Si mitigates the drought stress and improves production. Sonobe et al., (2017) studied the positive effects of $\mathrm{Si}$ on sorghum root response to drought stress, they found that the roots of plants treated with $\mathrm{Si}$ absorbed more water compared with control which increased the dry weight and reduced the osmotic potential in the roots. Deposited Si in the plants prevents the compression of xylem during high transpiration rate under drought stress (Mitani and Ma, 2005). In a pot experiment silicon $\mathrm{Si}(\mathrm{ml} / \mathrm{L}$ of $\mathrm{K} 2 \mathrm{SiO} 3$ per kilogram of soil) was used in two concentrations (100) and Si (200). Si (200) treatment improved chlorophyll content, leaf area index, root dry weight, leaf dry weight, shoot dry weight, total dry weight and specific leaf weight compared to untreated plants (Ahmad et al., 2011b). The application of $\mathrm{Si}$ enhances morphological characters and net yield in sorghum when applied under drought condition (Kaya et al., 2006). Coskun et al., 2016 examined the productive role of $\mathrm{Si}$ in many crop plants under drought and salinity stress, the results indicated that silicon mitigated drought and salinity stresses and increased the yield. This study investigates the mitigation role of silicon $\mathrm{Si}$ on the harsh environmental drought stresses in this arid land of Saudi Arabia.

\section{MATERIALS AND METHODS}

The research experiment was conducted in the Research Station of the Faculty of Meteorology, Environment and Arid Land Agriculture at Hada Al-Sham. The design used in this research was split plot design with main plots and subplots with three replications. The experimental area was divided into three main plots and three subplots. The irrigation was applied as main plots and Si was applied as subplots. The irrigation treatment levels are percentage of crop evapotranspiration's (ETc), and silicon treatments as (0 kg Si ha-1 $1 \mathrm{~kg}$ Si ha-1, $2 \mathrm{~kg} \mathrm{Si}$ ha-1 ). Surrounding the experimental plots, a buffer of two meter $(2 \mathrm{~m})$ wide was also cultivated with the same sorghum crop to make a fetch to reduce uneven weather and wind effects on the experimental plots.

The total number of plots were twenty seven $(3 * 3 * 3=27)$. The dimension of each experimental plot was $(4 \mathrm{~m} \times 2 \mathrm{~m})$ in size with one meter clearance between each plot to prevent inter-plot water flow. The experimental area was irrigated then ploughed twice, and levelled. 
Plots irrigation system

Four plastic tanks (6000 litters capacity of each) were installed, and all the tanks were interconnected and connected with irrigation pump. Bubbler irrigation system was used. Each plot was provided with eight bubblers of Rain Bird pressure compensating full circle trickle pattern 0.5 GPM discharge. The bubblers within each plot were mounted on two Poly Ethylene (PE) laterals pipelines of one inch size at one meter spacing. The bubblers were mounted using saddle of 1 inch* $1 / 2$ inch size (female threads) and six inch long PE risers. Each bubbler had built-in strainer to filter course sand and debris. Each PE lateral line supplied irrigation to three sub-plots running from east to west by applying same irrigation amount. The main and sub-main lines used were two inch PE pipe running from north to south outside the plots (flowmeter). Electrical pressure control valve was used at delivery of pump to deliver even pressure and prevent damage to the pump or lines while keeping bubblers' discharge constant. Flow rate was measured with seven bubblers in each plot and larger capacity pump and found to be very close to the standard discharge with small variation. Four pressure gauges were installed to check the operating pressure at pump, in the main line, in the sub main lines and in the laterals lines.

Method used in irrigation:

The water balance irrigation scheduling method involves estimation of the soil water balance by measuring the amount of rainfall, irrigation and then estimating the soil water depletion by calculating water consumed by the crop. It is a flexible method and can forecast irrigation needs in future depending upon weather forecast. The procedure of water balance irrigation scheduling is as follows:

AWSC $=$ FC - PWP

Where

AWSC: is the available water storage capacity of the soil $(\mathrm{mm} / \mathrm{m})$. treatments $(0,1$ and $2 \mathrm{~kg} / \mathrm{ha})$ at $(\mathrm{P} \leq 0.01)$ during all cuts.
TABLE 1. THE ANALYSIS OF VARIANCE FOR NUMBER OF TILLERS/M2, PLANT HEIGHT, FRESH FORAGE YIELD, DRY FORAGE YIELD, ROOT VOLUME AND IRRIGATION WATER USE EFFICIENCY (IWUE) FOR SORGHUM CROP UNDER THE EFFECT OF IRRIGATION AND SILICON TREATMENTS AND THEIR INTERACTION DURING 2017 CROP SEASON.

\begin{tabular}{|c|c|c|c|c|c|c|}
\hline \multirow{8}{*}{$\begin{array}{l}\text { 1st } \\
\text { Cut }\end{array}$} & \multirow[b]{2}{*}{ Source of variance } & \multirow[b]{2}{*}{ df } & \multicolumn{3}{|c|}{ parameters } & \multirow[b]{2}{*}{$\begin{array}{c}\text { Root } \\
\text { Volume }(\mathrm{m} 3)\end{array}$} \\
\hline & & & $\begin{array}{c}\begin{array}{c}\text { Number } \\
\text { of } \\
\text { tillers } / \mathbf{m} 2\end{array} \\
\end{array}$ & $\begin{array}{l}\text { Plant height } \\
\quad(\mathrm{cm})\end{array}$ & $\begin{array}{c}\text { Fresh forage } \\
\text { Yield } \\
\text { (t/ha) }\end{array}$ & \\
\hline & Replication & 2 & $129.33 \mathrm{NS}$ & $7.14 \mathrm{NS}$ & $4.48 \mathrm{NS}$ & $\mathrm{x}$ \\
\hline & Irrigation(Irri) & 2 & $82.33 \mathrm{NS}$ & $791.81 * *$ & $164.73 * *$ & $\mathrm{x}$ \\
\hline & Error (a) & 4 & 319.83 & 1.42 & 0.99 & $\mathrm{x}$ \\
\hline & Silicon $(\mathrm{Si})$ & 2 & $217.44 *$ & $529.03 * *$ & $291.27 * *$ & $\mathrm{x}$ \\
\hline & Irri* $\mathrm{Si}$ & 4 & $12.44 \mathrm{NS}$ & $11.98^{*}$ & $3.72 *$ & $\mathrm{x}$ \\
\hline & Error (b) & 12 & 37.27 & 3.33 & 0.99 & $\mathrm{x}$ \\
\hline \multirow{6}{*}{$\begin{array}{l}\text { 2nd } \\
\text { cut }\end{array}$} & Replication & 2 & $0.11 \mathrm{NS}$ & $3.37 \mathrm{NS}$ & $3.01 \mathrm{NS}$ & $\mathrm{x}$ \\
\hline & Irrigation(Irri) & 2 & $315.11 * *$ & $611.48 * *$ & $133.73 * *$ & $\mathrm{x}$ \\
\hline & Error (a) & 4 & 0.88 & 1.06 & 0.83 & $\mathrm{x}$ \\
\hline & Silicon $(\mathrm{Si})$ & 2 & $137.44 * *$ & $426.45^{* * *}$ & $232.99 * *$ & $\mathrm{x}$ \\
\hline & Irri* $\mathrm{Si}$ & 4 & $8.22 \mathrm{NS}$ & $8.98 \mathrm{NS}$ & $2.96 \mathrm{NS}$ & $\mathrm{x}$ \\
\hline & Error (b) & 12 & 3.07 & 3.11 & 0.94 & $\mathrm{x}$ \\
\hline \multirow{6}{*}{$\begin{array}{l}\text { 3rd } \\
\text { cut }\end{array}$} & Replication & 2 & $0.25 \mathrm{NS}$ & $5.48 \mathrm{NS}$ & $3.56 \mathrm{NS}$ & 0.0000014 \\
\hline & Irrigation(Irri) & 2 & $226.81 * *$ & $786.03 * *$ & $158.88 * *$ & $0.0000598 * *$ \\
\hline & Error (a) & 4 & 0.70 & 1.31 & 0.98 & 0.0000004 \\
\hline & Silicon $(\mathrm{Si})$ & 2 & $98.25^{* * *}$ & $529.59 * *$ & $276.65 * *$ & $0.000148 * *$ \\
\hline & Irri* $\mathrm{Si}$ & 4 & $5.87 \mathrm{NS}$ & $10.59 \mathrm{NS}$ & $3.52 \mathrm{NS}$ & $0.0000033^{*}$ \\
\hline & Error & 12 & 2.27 & 3.48 & 1.11 & 0.00000092 \\
\hline
\end{tabular}

FC: is the field capacity (volumetric moister content (\%) (Upper limit).

PWP: is the permanent wilting point (volumetric moister content $(\%) \quad$ (Lower limit).

Evapotranspiration (ET) is the combination of two separate processes (Evaporation and Transpiration) whereby water is lost from the soil surface by evaporation and from the crops by transpiration.

Planting of sorghum:

Sorghum fodder local variety Jizani was sown. After installation of irrigation system and levelling Sorghum crop was sown manually in all plots. The spacing between rows kept at $30 \mathrm{~cm}$. Seeds were placed at $5 \mathrm{~cm}$ depth and then covered manually. Six rows were sown in each plot. Six rows were also sown as buffer area at the same time. Seed rate of $60 \mathrm{~kg} / \mathrm{ha}$ was used.

The crop was sown on 13th March 2017 and the 3rd cut was harvested on 30th September 2017. The duration of 1st cut was 61 days (Sowing date 13th March and Harvesting date 13th May).

Application of silicon treatments

Irrigation and $\mathrm{Si}$ treatments were applied after proper germination and crop establishment period at five leaves stage. treatments $(1 \mathrm{~kg} / \mathrm{ha}=0.1 \mathrm{gram} / \mathrm{m} 2$ and $2 \mathrm{~kg} / \mathrm{ha}=0.2$ $\operatorname{gram} / \mathrm{m} 2$ )

\section{RESULTS}

\section{ANALYSIS OF VARIANCE (ANOVA) FOR STUDIED SORGHUM CROP PARAMETERS DURING GROWING SEASON 2017.}

The ANOVA table (Table 1) indicated highly significant differences in results of the studied growth parameters of sorghum ( number of tillers per square meter, plant height, fresh forage yield, and root volume) between irrigation treatments $(100 \%, 80 \%$ and $60 \%$ of ETc) and $\mathrm{Si}$ foliar 
Effect of irrigation and Si levels on number of tillers/m2 of Sorghum crop:

Analysis of variance:

Table (1) illustrates that during first cut no significant differences were observed by irrigation treatments on number of tillers per $\mathrm{m} 2$ in sorghum, but there were significant differences by irrigation treatments and $\mathrm{Si}$ treatments on number of tillers during second and third cuts. Means comparisons of number of tillers/ $\mathrm{m} 2$ of sorghum crop.

Number of tillers per square meter was not affected very much by Si during the first cut. While during 2nd and 3rd cut the decrease in irrigation amount from $100 \%$ to $60 \%$ of ETc reduced the number of tillers per square meter by $11.2 \%$ but tiller number increased by $10.11 \%$ by application of $\mathrm{Si}$ from 0-2 kg/ha, (Table 2). The interaction of irrigation and $\mathrm{Si}$ treatments shows no significant effect on number of tillers per square meter during all cuts.

TABLE 2. MEANS OF NUMBER OF TILLERS/M2 OF SORGHUM CROP UNDER THE EFFECT OF VARYING LEVELS OF IRRIGATION AND SILICON DURING 2017 CROP SEASON.

\begin{tabular}{|c|c|c|c|}
\hline \multirow[t]{2}{*}{ Treatments levels } & \multicolumn{3}{|c|}{ Number of cuts of Sorghum crop } \\
\hline & 1st cut & 2nd cut & 3rd cut \\
\hline \multicolumn{4}{|l|}{ Irrigation levels (\% ETc) } \\
\hline 100 & $74.00 \mathrm{a}$ & $116.44 \mathrm{a}$ & $99.11 \mathrm{a}$ \\
\hline 80 & $71.66 \mathrm{a}$ & $111.55 \mathrm{~b}$ & $94.88 \mathrm{~b}$ \\
\hline 60 & $77.66 \mathrm{a}$ & $104.66 \mathrm{c}$ & $89.11 \mathrm{c}$ \\
\hline LSD (0.05) & 23.41 & 1.23 & 1.09 \\
\hline \multicolumn{4}{|l|}{ Silicon levels (kg/ha) } \\
\hline $\mathbf{0}$ & $71.33 \mathrm{~b}$ & $107.22 \mathrm{c}$ & $91.33 \mathrm{c}$ \\
\hline 1 & $71.88 \mathrm{~b}$ & $110.44 \mathrm{~b}$ & $93.88 \mathrm{~b}$ \\
\hline 2 & $80.11 \mathrm{a}$ & $115.00 \mathrm{a}$ & $97.88 \mathrm{a}$ \\
\hline LSD (0.05) & 6.27 & 1.80 & 1.55 \\
\hline
\end{tabular}

* MEANS FOLLOWED BY THE SAME LETTER ARE NOT SIGNIFICANTLY DIFFERENT ACCORDING TO LSD AT P $\leq 0.05$

Effect of irrigation and Si levels on plant height of Sorghum crop:

Means comparisons of plant height of Sorghum crop:

During 1st cut the decrease in irrigation amount from $100 \%$ to $60 \%$ of ETc reduced the plant height from $114.77 \mathrm{~cm}$ to
$96.22 \mathrm{~cm}(16.16 \%)$ while increased the level of Si from $0-2$ $\mathrm{kg} / \mathrm{ha}$ increased them from $97.00 \mathrm{~cm}$ to $112.33 \mathrm{~cm}(13.64 \%)$, the same trend was followed during 2 nd cut, the decrease was $15.86 \%$ and increase was $13.56 \%$, during 3 rd cut the decrease was $15.43 \%$ and increase was $13.93 \%$ (Table 3 ).

TABLE 3. MEANS OF PLANT HEIGHT (CM) OF SORGHUM CROP UNDER THE EFFECT OF VARYING LEVELS OF IRRIGATION AND SILICON DURING 2017 CROP SEASON.

\begin{tabular}{|c|c|c|c|}
\hline \multirow[t]{2}{*}{ Treatments levels } & \multicolumn{3}{|c|}{ Number of cuts of Sorghum crop } \\
\hline & 1st cut & 2nd cut & 3rd cut \\
\hline \multicolumn{4}{|c|}{ Irrigation levels (\% ETc) } \\
\hline 100 & $114.77 \mathrm{a}$ & $103.14 \mathrm{a}$ & $120.22 \mathrm{a}$ \\
\hline 80 & $103.11 \mathrm{~b}$ & $93.17 \mathrm{~b}$ & $109.00 \mathrm{~b}$ \\
\hline 60 & $96.22 \mathrm{c}$ & $86.78 \mathrm{c}$ & $101.66 \mathrm{c}$ \\
\hline LSD (0.05) & 1.56 & 1.35 & 1.50 \\
\hline \multicolumn{4}{|l|}{ Silicon levels (kg/ha) } \\
\hline $\mathbf{0}$ & $97.00 \mathrm{c}$ & $87.65 \mathrm{c}$ & $102.77 \mathrm{c}$ \\
\hline 1 & $104.77 \mathrm{~b}$ & $94.04 \mathrm{~b}$ & $110.00 \mathrm{~b}$ \\
\hline 2 & $112.33 \mathrm{a}$ & $101.41 \mathrm{a}$ & $118.11 \mathrm{a}$ \\
\hline LSD (0.05) & 1.87 & 1.81 & 1.91 \\
\hline
\end{tabular}

* MEANS FOLLOWED BY THE SAME LETTER ARE NOT SIGNIFICANTLY DIFFERENT ACCORDING TO LSD AT P $\leq 0.05$

Effect of interaction between irrigation and Si levels on plant height of Sorghum crop:

Table (4) indicated that under each irrigation level increase in $\mathrm{Si}$ level from 0 to $2 \mathrm{~kg} / \mathrm{ha}$ resulted in increase in plant height. The maximum plant height was recorded during $1 \mathrm{st}$ cut as $122.67 \mathrm{~cm}$, during $2 \mathrm{nd}$ cut $110.47 \mathrm{~cm}$ and during $3 \mathrm{rd}$ cut as $127.67 \mathrm{~cm}$. 
TABLE 4: EFFECT OF INTERACTION BETWEEN IRRIGATION AND SI LEVELS ON MEANS OF NUMBER OF PLANT HEIGHT (CM) OF SORGHUM CROP DURING 2017 CROP SEASON.

\begin{tabular}{|c|c|c|c|c|}
\hline \multirow{6}{*}{ 1st Cut } & \multirow[t]{2}{*}{ Irrigation levels (\% of ETc) } & \multicolumn{3}{|c|}{ Silicon levels (kg/ha) } \\
\hline & & 0 & 1 & 2 \\
\hline & 100 & 105.00 & 116.67 & 122.67 \\
\hline & 80 & 97.67 & 101.67 & 110.00 \\
\hline & 60 & 88.33 & 96.00 & 104.33 \\
\hline & LSD (0.05) & & 3.24 & \\
\hline \multirow{6}{*}{ 2nd Cut } & \multirow[t]{2}{*}{ Irrigation levels (\% of ETc) } & \multicolumn{3}{|c|}{ Silicon levels $(\mathrm{kg} / \mathrm{h} \mathrm{a})$} \\
\hline & & 0 & 1 & 2 \\
\hline & 100 & \multirow{3}{*}{$\begin{array}{c}94.5388 .33 \\
80.10\end{array}$} & 104.43 & \multirow{3}{*}{$\begin{array}{r}110.47 \\
99.60 \\
94.17 \\
\end{array}$} \\
\hline & 80 & & \multirow{2}{*}{$\begin{array}{l}91.60 \\
86.10 \\
\end{array}$} & \\
\hline & 60 & & & \\
\hline & LSD (0.05) & \multicolumn{3}{|c|}{ NS } \\
\hline \multirow{6}{*}{ 3rd Cut } & \multirow[t]{2}{*}{ Irrigation levels (\% of ETc) } & \multicolumn{3}{|c|}{ Silicon levels (kg/h a) } \\
\hline & & 0 & 1 & 2 \\
\hline & 100 & \multirow{3}{*}{$\begin{array}{c}111.00 \\
103.33 \\
94.00 \\
\end{array}$} & 122.00 & 127.67 \\
\hline & 80 & & 107.00 & 116.67 \\
\hline & 60 & & 101.00 & 110.00 \\
\hline & LSD (0.05) & \multicolumn{3}{|c|}{ NS } \\
\hline
\end{tabular}

* MEANS FOLLOWED BY THE SAME LETTER ARE NOT SIGNIFICANTLY DIFFERENT ACCORDING TO LSD AT P $\leq 0.05$

\section{Effect of irrigation and Si levels on fresh forage yield of} Sorghum crop:

Means comparisons of fresh forage yield of Sorghum crop:

The production of forage yield was decreased from $45.80 \mathrm{t} / \mathrm{ha}$ to $37.43 \mathrm{t} / \mathrm{ha}(18.27 \%)$ due to reduction in irrigation water supply from $100 \%$ to $60 \%$ of ETc, simultaneously fresh forage yield of Sorghum crop increased by application of $\mathrm{Si}$ from 0 to $2 \mathrm{~kg} / \mathrm{ha}$ to reach averages from 35.93 t/ha to 47.19 t/ha $(23.86 \%)$ during 1 st cut. The same trend was followed during 2 nd cut and 3rd cut with water stress resulting in reduction in forage yield from $41.27 \mathrm{t} / \mathrm{h}$ to $33.75 \mathrm{t} / \mathrm{ha}$ $(18.22 \%)$ and from 44.99 t/ha to 36.79 t/ha $(18.22 \%)$ reduction during the two cuttings respectively, and application of $\mathrm{Si}$ compensated this reduction by increase in forage yield from $32.40 \mathrm{t} / \mathrm{ha}$ to $42.47 \mathrm{t} / \mathrm{ha}(23.71 \%)$, and from $35.31 \mathrm{t} /$ ha to $46.29 \mathrm{t} / \mathrm{ha}(23.72 \%)$ (Table 4.6$)$ during 2 rd cut and 3rd cut respectively (Table 5).

TABLE (5): MEANS OF FRESH FORAGE YIELD (T/HA) OF SORGHUM CROP UNDER THE EFFECT OF VARYING LEVELS OF IRRIGATION AND SILICON DURING 2017 CROP SEASON.

\begin{tabular}{|c|c|c|c|}
\hline \multirow{2}{*}{ Treatments levels } & \multicolumn{3}{|c|}{ Number of cuts of Sorghum crop } \\
\hline & 1st cut & 2nd cut & 3rd cut \\
\hline \multicolumn{4}{|l|}{ Irrigation levels (\% ETc) } \\
\hline 100 & $45.80 \mathrm{a}$ & $41.27 \mathrm{a}$ & $44.99 \mathrm{a}$ \\
\hline 80 & $40.04 \mathrm{~b}$ & $36.04 \mathrm{~b}$ & $39.28 \mathrm{~b}$ \\
\hline 60 & $37.43 \mathrm{c}$ & $33.75 \mathrm{c}$ & $36.79 \mathrm{c}$ \\
\hline LSD (0.05) & 1.3 & 1.19 & 1.3 \\
\hline \multicolumn{4}{|l|}{ Silicon levels (kg/ha) } \\
\hline $\mathbf{0}$ & $35.93 \mathrm{c}$ & $32.40 \mathrm{c}$ & $35.31 \mathrm{c}$ \\
\hline 1 & $40.15 b$ & $36.19 \mathrm{~b}$ & $39.45 \mathrm{~b}$ \\
\hline 2 & $47.19 \mathrm{a}$ & $42.47 \mathrm{a}$ & $46.29 \mathrm{a}$ \\
\hline LSD (0.05) & 1.02 & 0.99 & 1.08 \\
\hline
\end{tabular}

Effect of interaction between irrigation and Si levels on fresh forage yield of Sorghum crop:

The interaction of irrigation and $\mathrm{Si}\left(\mathrm{Irr} .{ }^{*} \mathrm{Si}\right)$ levels on fresh forage yield was also significant $(\mathrm{P} \leq 0.05)$ during 1 st cut while it was non-significant $(\mathrm{P} \leq 0.05)$ during 2 nd and 3 rd cut. Interaction between irrigation and $\mathrm{Si}$ treatments means (Table 6) showed within same irrigation levels, the increase in $\mathrm{Si}$ dose increased the fresh forage yield ( $\mathrm{t} / \mathrm{ha}$ ) and the decrease in irrigation levels (increase drought stress) decreased the fresh forage yield according to LSD, compared with control during all cuts. For the 1st cut the maximum fresh forage yield was $52.33(\mathrm{t} / \mathrm{ha})$ while it was $47.10(\mathrm{t} / \mathrm{ha})$ for the 2 nd cut and 51.33 (t/ha) for the 3 rd one. In the 1 st cut, compared with controls, the plants treated with Si treatment two (2kg Si ha-1) and irrigation treatment one (80\%ETc) gave a higher yield 44.87 (t/ha), while it was $40.38 \mathrm{t} / \mathrm{ha}$ for the 2 nd cut and $44.03 \mathrm{t} / \mathrm{ha}$ for the $3 \mathrm{rd}$ one. 
TABLE (6): EFFECT OF INTERACTION BETWEEN IRRIGATION AND SI LEVELS ON MEANS OF FRESH FORAGE YIELD (T/HA) OF SORGHUM CROP DURING 2017 CROP SEASON

\begin{tabular}{|c|c|c|c|c|}
\hline \multirow{6}{*}{ 1st Cut } & \multirow{2}{*}{$\begin{array}{c}\text { Irrigation levels (\% of } \\
\text { ETc) }\end{array}$} & \multicolumn{3}{|c|}{ Silicon levels (kg/ha) } \\
\hline & & $\mathbf{0}$ & 1 & 2 \\
\hline & 100 & \multirow{3}{*}{$\begin{array}{l}40.3336 .10 \\
31.37\end{array}$} & \multirow{3}{*}{$\begin{array}{l}44.7339 .17 \\
36.57\end{array}$} & \multirow{3}{*}{$\begin{array}{l}52.3344 .87 \\
44.40\end{array}$} \\
\hline & 80 & & & \\
\hline & 60 & & & \\
\hline & LSD (0.05) & \multicolumn{3}{|c|}{1.77} \\
\hline \multirow{6}{*}{ 2nd Cut } & \multirow{2}{*}{$\begin{array}{c}\text { Irrigation levels (\% of } \\
\text { ETc) }\end{array}$} & \multicolumn{3}{|c|}{$\mathrm{S}$ ilicon levels $(\mathrm{kg} / \mathrm{h} \mathrm{a})$} \\
\hline & & 0 & 1 & 2 \\
\hline & 100 & \multirow{3}{*}{$\begin{array}{l}36.4732 .49 \\
28.25\end{array}$} & \multirow{3}{*}{$\begin{array}{l}40.2635 .25 \\
33.08\end{array}$} & \multirow{3}{*}{$\begin{array}{l}47.1040 .38 \\
39.94\end{array}$} \\
\hline & 80 & & & \\
\hline & 60 & & & \\
\hline & LSD (0.05) & \multicolumn{3}{|c|}{ NS } \\
\hline \multirow{6}{*}{ 3rd Cut } & \multirow{2}{*}{$\begin{array}{c}\text { Irrigation levels (\% of } \\
\text { ETc) }\end{array}$} & \multicolumn{3}{|c|}{$\mathrm{S}$ ilicon levels $(\mathrm{kg} / \mathrm{h}$ a) } \\
\hline & & 0 & 1 & 2 \\
\hline & 100 & \multirow{3}{*}{$\begin{array}{c}39.7735 .40 \\
30.80\end{array}$} & \multirow{3}{*}{$\begin{array}{l}43.8738 .43 \\
36.03\end{array}$} & \multirow{3}{*}{$\begin{array}{l}51.3344 .03 \\
43.53\end{array}$} \\
\hline & 80 & & & \\
\hline & 60 & & & \\
\hline & LSD (0.05) & \multicolumn{3}{|c|}{ NS } \\
\hline
\end{tabular}

Effect of irrigation and Si levels on root volume of sorghum crop:

Means comparisons of root volume of Sorghum crop: Results of table (7) shows that decrease in irrigation level from $100 \%$ to $60 \%$ of ETc increased the root volume, and also increase in Si dose from 0 to $2 \mathrm{~kg} / \mathrm{ha}$ also increased the root volume (Table 7).

Interaction effect of Irrigation and Si levels on the root volume of Sorghum crop.

The interaction of irrigation and $\mathrm{Si}$ (Irri*Si) levels and its effect on root volume of sorghum forage plant is significant $(\mathrm{P} \leq 0.05)$. According to the values of the interaction between irrigation and Si treatments means (Table 8), it is clear that within each irrigation level, the increase in $\mathrm{Si}$ dose resulted in an increased in the root volume, and also the decrease in irrigation level (increase drought stress) within each $\mathrm{Si}$ treatment level increased the root volume according to LSD compared with control. The maximum root volume $(0.030$ m3) was observed in the highest deficit irrigation $(60 \%$ ETc) and $2 \mathrm{~kg}$ ha- 1 Si dose.

With passage of time, more Si was accumulated in the plants causing lateral growth in the roots. The root depth was almost same in all plots which increased gradually. The increase in root volume increased the water uptake and consequently the studied crop parameters were improved. The increase in root volume also reduced moisture level in the soil near harvesting due to more water uptake efficiency.

TABLE (7): MEANS OF ROOT VOLUME OF SORGHUM CROP UNDER THE EFFECT OF VARYING LEVELS OF IRRIGATION AND SILICON DURING 2017 CROP SEASON (FINAL HARVESTING).

\begin{tabular}{|c|c|}
\hline Treatments levels & Root volume (m3) of sorghum crop \\
\hline Irrigation levels (\% of ETc) & \\
\hline 100 & $0.020 \mathrm{c}$ \\
\hline 80 & $0.022 \mathrm{~b}$ \\
\hline 60 & $0.025 \mathrm{a}$ \\
\hline LSD $(0.05)$ & 0.0009 \\
\hline Silicon levels $(\mathrm{kg} / \mathrm{ha})$ & $0.019 \mathrm{c}$ \\
\hline 1 & $0.021 \mathrm{~b}$ \\
\hline 2 & $0.027 \mathrm{a}$ \\
\hline $\operatorname{LSD}(0.05)$ & 0.001 \\
\hline
\end{tabular}

TABLE (8): EFFECT OF INTERACTION BETWEEN IRRIGATION AND SI LEVELS ON MEANS OF ROOT VOLUME (M3) OF SORGHUM CROP DURING 2017 CROP SEASON (FINAL HARVESTING)

\begin{tabular}{|c|c|c|c|c|c|}
\hline \multicolumn{6}{|c|}{ Root volume (m3) of Sorghum at final harvesting } \\
\hline \multirow{6}{*}{$\begin{array}{c}\text { Root volume at } \\
\text { harvesting }\end{array}$} & \multirow{2}{*}{ Irrigation levels (\% of ETc) } & \multicolumn{3}{|c|}{ Silicon levels (kg/ha) } & \multirow[b]{2}{*}{2} \\
\hline & & 0 & & & \\
\hline & 100 & \multirow{3}{*}{$\begin{array}{l}0.016 \\
0.020\end{array}$} & \multirow{3}{*}{$\begin{array}{l}0.0190 .020 \\
0.024\end{array}$} & \multirow[t]{3}{*}{0.021} & \multirow{3}{*}{$\begin{array}{l}0.0240 .026 \\
0.030\end{array}$} \\
\hline & 80 & & & & \\
\hline & 60 & & & & \\
\hline & LSD (0.05) & \multicolumn{3}{|c|}{0.0017} & \\
\hline
\end{tabular}




\section{DISCUSSION}

Si helps plants to acclimatize under drought condition by modifying a variety of physiological processes, including stomatal conductance, transpiration rate, water relations and synthesis of photosynthetic pigments, and improving nutrient uptake and decreasing $\mathrm{Na}+$ content in leaf tissue, thereby improving growth and yield of plants. Many previous studies have been conducted on Si to investigate its mechanisms of environmental stresses alleviation in crop plants (Kim et al., 2014a; Martínez et al., 2015). Drought stress represented in the different water regimes $(80 \%, 60 \%$ Ec ) significantly affected sorghum growth parameters (number of tillers/m2, plant height, fresh forage yield, and root volume). The results indicated that drought conditions particularly during 2 nd cut decreased plant height $(15.50 \%)$ and fresh yield $(22 \%)$ of sorghum. This result obtained agree with what has been obtained by (Anjum et al., 2003a; Bhatt \& Srinivasa Rao, 2005; Kusaka et al., 2005; Shao et al., 2008). The foliar application of silicon increased number of tillers per square meter (almost $1.5 \%$ ), plant height (14\%), fresh yield (25\%) and root volume as compared to control. During 2nd cut number of tillers per square meter increased as compared with 1 st cut and the trend started decreasing during 3 rd cut. The reason of more branching in Si treated plots is probably due to more water uptake efficiency of $\mathrm{Si}$, nature of ratoon crops and increase root depth of sorghum. These results agree with previous studies on tillering effects by application of $\mathrm{Si}$ on crops (Tabassam et al., 2014; Cossani and Reynolds, 2012). Also the results of mitigating effect of Si application on drought effects on crop plants growth was approved by number of researchers (Specht et al., 2001 on soybean , Wu et al., 2008 on citrus, Heuer and Nadler, 1995 on potato, Sankar et al., 2007-08 on Abelmoschus esculentus; Manivannan et al., 2007a on Vigna unguiculata; Zhang et al. 2004 on soybean). The plant height, dry matter, chlorophyll content, relative water content, stomatal conductance was increased in wheat when treated with Si under drought stress (Gong et al., 2003; Hattori et al., 2005; Eneji et al., 2005), and in Sorghum (Ahmad et al., 2011b). May be Si is accumulated more in the root than in the shoot, which might be the probable reason of the increase in root volume enabling the movement of roots in search of more water to compensate with drought condition. These finding are similar to some previous researchers (Mohammad and Rahimi 2011) working on Portulaca oleracea L. and (Gau et al., 2006) working on alfalfa.

\section{CONCLUSION}

Growth of sorghum under irrigation water stress i.e. under reduction of irrigation water from $100 \%$ to $60 \%$ ETc resulted in significant reduction in growth components of sorghum. Plant height, number of tillers and total fresh forage yield decreased with decrease in irrigation water from $100 \%$ to $8 \%$ and $60 \%$ ETc. The foliar application of silicon on sorghum leaves increased number of tillers per square meter (almost $1.5 \%$ ), plant height (14\%), fresh yield (25\%) and root volume as compared to control in all cuttings. Foliar application of silicon mitigated and alleviated the harsh conditions created by drought stress on sorghum plant growth. Silicon when applied at concentration of $2 \mathrm{~kg} / \mathrm{ha}$ with the water stress level $2(80 \% \mathrm{ETc})$ gave the maximum plant height $(109.0 \mathrm{~cm})$ and the maximum fresh forage yield (44.00 t/ha) compared with control treatment ( $100 \% \mathrm{ETc})$. Root volume was maximum $(0.031 \mathrm{~m} 3)$ under $60 \% \mathrm{ETc}$ and $2 \mathrm{~kg}$ ha- $1 \mathrm{Si}$ treatments compared with control $(100 \%$ ETc). For production of sorghum fodder under the arid land environmental conditions of Saudi Arabia deficit irrigation with (80\% and 60\% ETc) with application of $2 \mathrm{~kg}$ ha-1 silicon ( $\mathrm{Si}$ ) as foliar spray seems a reasonable option than irrigating the crop with $100 \%$ ETc due to scarcity of irrigation water in this country. It gives higher yields than $100 \%$ irrigation and optimum moister level in the root zoon.

\section{REFERENCES}

[1] M. Ahmad, F. U. Hassen, U. Qadeer and M. A. Aslam. "Silicon application and drought tolerance mechanism of sorghum". Afr. J. Agric. Res., 6: 594-607. 2011 b.

[2] F. Anjum, Yaseen, M. Rasul, E. Wahid, A and S. Anjum. "Water stress in barley (Hordeum vulgare L.). Effect on morphological characters". Pak. J. Agric. Sci, 40: 43-44. 2003 a.

[3] S. A. Anjum, X. Y. Xie, L. C. Wang, M. F. Saleem, C. Man and C. W. Lei. "Morphological, physiological and biochemical responses of plants to drought stress". Afr. J. Agr. Res., 6: 2026-2032. 2011 b.

[4] R. M. Bhatt and N. K. S. Rao. "Influence of pod load response of okra to water stress“. Ind. J. Plant Physiol., 10: 54-59. 2005.

[5] D. Coskun, D. T. Britto, W. Q. Huynh and H. J. Kronzucker. "The role of silicon in higher plants under salinity and drought stress". Front. Plant Sci., 7: 1-7. 2016.

[6] C. M. Cossani, M. P. Reynolds. "Physiological traits for improving heat tolerance in wheat". Plant Physiol., 160: 1710-1718. 2012.

[7] P.E. Dreesen, H.J. De Boeck, I.A. Janssens, I. Nijs. "Summer heat and drought extremes trigger unexpected changes in productivity of a temperate annual/biannual plant community". Environ. Exp. Bot. 79: 21-30. 2012

[8] A. E. Eneji, S. Inanaga, S. Muranaka, J. Li, T. Hattori, P. A, W. Tsuji. "Growth and nutrient use in four grasses under drought stress as mediated by silicon fertilizers“. J. Plant Nutr, 31: 355-365. 2008.

[9] X. Gau, C. Zou, L. Wang, and F. Zhang. "Silicon decreases transpiration rate and conductance from stomata of maize plants". J. Plant Nutr. 29:1637-1647. 2006.

[10] H. J. Gong, K. M. Chen, G. C. Chen, S. M. Wang and C. L. Zhang. "Effects of silicon on growth of wheat under drought". J. Plant Nutr, 26: 1055-1063. 2003

[11] T. Hattori, H. Inanaga, H. Araki, P., S. Morita, M. Luxova and A. Lux. "Application of silicon enhanced drought tolerance in Sorghum bicolor". Plant Physiol, 123: 459-466.2005.

[12] B. Heuerand, A. Nadler. "Growth, development and yield of potatoes under salinity and water deficit”. Aust. J. Agric. Res., 46: 1477-1486. 1995.

[13] M. J. Hodson, P. J. White, A. Mead and M. R. Broadley. "Phylogenetic variation in the silicon composition of plants". Annu. Bot, 96: 1027-1046. 2005.

[14] C. Kaya, L. Tuna and D. Higgs. "Effect of silicon on plant growth and mineral nutrition of maize grown under water-stress conditions“. J. Plant Nutr. 29: 1469-1480. 2006

[15] T. Keenan, S. Sabate, C. Gracia. "The importance of mesophyll conductance in regulating forest ecosystem productivity during drought periods". Global Change Biol., 16: 1019-1034. 2010.

[16] Y.H. Kim, A.L. Khan Waqas, M. Shim, J.K. Kim, D.H. Lee, K.Y. and I.J. Lee. "Silicon Application to Rice Root Zone Influenced the Phytohormonal and Antioxidant Responses under Salinity Stress". J. Plant Growth Regul. 33: 137-149. 2014a.

[17] M. Kusaka, M. Ohta and T. Fujimura. "Contribution of inorganic components to osmotic adjustment and leaf folding for drought tolerance in pearl millet“. Plant Physiol, 125: 474-489. 2005. 
[18] D. B. Lobell, W. Schlenker, J. Costa-Roberts. "Climate trends and global crop production since 1980". Science 333: 616-620. 2011

[19] J. F. Ma, E. Takahashi. "Soil, Fertilizer, and Plant Silicon Research in Japan. Elsevier Science, Amsterdam, The Neitherland. 2002.

[20] P. Manivannan, C. A. Jaleel, A. Kishorekumar, B. Sankar, R. Somasundaram, R. Sridharan, R. Panneerselvam. "Changes in antioxidant metabolism of Vigna unguiculata (L.) Walp. by propiconazole under water deficit stress". Colloids Surf. B: Biointerfaces, 57: 69-72. 2007a.

[21] M. Marsalis, S. Angadi and F. C. Govea. "Effect of seeding and nitrogen rates on limited irrigated corn and forage sorghum yield and nutritive value". In Abstracts: Annual meeting, Western Society of Crop Sci. Ft. Collins, Co. 2009

[22] R. Martínez, Espejo, A., Sierra, M., Ortiz-Bernad, I., Correa, D., Bedmar, E., LópezJurado, M. and Porres, J.M. "Co-inoculation of Halomonas maura and Ensifer meliloti to improve alfalfa yield in saline soils". App. Soil Ecol. 87: 81-86. 2015.

[23] N. Mitaniand, J. F. Ma. "Uptake system of silicon in different plant species". J. Exp. Bot., 56: 1255-1261. 2005.

[24] R. Mohammadian, M. Moghaddam, H. Rahimian and S. Y. Sadeghian. "Effect of early season drought stress on growth characteristics of sugar beet genotypes". Turkisk J. Bot., 29: 357368. 2005.

[25] J.A. Rollins, E. Habte, S.E. Templer, T. Colby, J. Schmidt, M. von Korff. "Leaf proteome alterations in the context of physiological and morphological responses to drought and heat stress in barley (Hordeum vulgare L.)". J.Exp. Bot. 64(11): 3201-3212. 2013.

[26] B. Sankar, C. A. Jaleel, P. Manivannan, A. Kishorekumar, R. Somasundaram, R. Panneerselvam. "Effect of paclobutrazol on water stress amelioration through antioxidants and free radical scavenging enzymes in Arachis hypogaea L. Colloids Surf”. B: Biointerfaces, 60: 229-235. 2007.

[27] B. Sankar, C. A Jaleel, P. Manivannan, A. Kishorekumar, R. Somasundaram, R. Panneerselvam. Relative efficacy of water use in five varieties of Abelmoschus esculentus (L.) Moench under water- limited conditions. Colloids Surf. B: Biointerfaces, 62: 125-129. 2008

[28] H. B. Shao, L. Y. Chu, M. A. Shao, C. A. Jaleel and M. Hong-Mei. "Higher plant antioxidants and redox signaling under environmental stresses." Comp. Rend. Biol, 331: 433-441. 2008.

[29] K. Sonobe, T. Hattori, P. An, W. Tsuji, A. E. Eneji, S. Kobayashi. "Effect of silicon application on sorghum root responses to water stress". J. Plant Nutr. 34: 71-82. 2017.

[30] J. E. Specht, K. Chase, M. Macrander, G. L. Graef, J. Chung, J. P. Markwell, M. Germann, J. H. Orf and K. G. Lark. "Soybean response to water. A QTL analysis of drought tolerance". Crop Sci., 41: 493 509. 2001.

[31] M. A. R. Tabassam, M. Hussain, A. Sami, I. Shabbir, M. A. N Bhutta, M. Mubusher and S. Ahmad. "Impact of drought on the growth and yield of wheat". Sci. Agri., 7: 11-18. 2014.

[32] K.E. Trenberth. "Changes in precipitation with climate change". Clim. Res. 47: 123-138. 2011.

[33] V. Vadez, J. Kholova, S. Choudhary, P. Zindy, M. Terrier, L. Krishnamurth, P.R. Kumar, N.C. Turner. Whole plant response to drought under climate change. In: Crop adaptation to climate change (Eds S.S. Yadav, R. Redden, J.L. Hatfield, H. Lotze-Campen, A.E. Hall). Chichester-Wiley-Blackwell. 2011.

[34] Wahid, S. Gelani, M. Ashraf, M. R. Foolad. "Heat tolerance in plants: an overview". Environ. Exp. Bot. 61: 199-223. 2007.

[35] A. Wallace. "Participation of silicon in cation-anion balance as a possible mechanism for aluminum and iron tolerance in some Gramineae". J. Plant Nutr, 16: 547-553. 1993.

[36] Q. S. Wu, R. X. Xia, Y. N. Zou. "Improved soil structure and citrus growth after inoculation with three arbuscular mycorrhizal fung under drought stress". Eur. J. Soil Biol. 2008.

[37] M. Zhang, L. Duan, Z. Zhai, J. Li, X. Tian, B. Wang, Z. He and Z. Li. Effects of plant growth regulators on water deficit-induced yield loss in soybean. Proceedings of the 4th International Crop Science Congress, Brisbane, Australia. 2004. 